\title{
Discussion on the Perfection of the Disabled Care System in China -From the Aspect of Protecting the Rights and Interests
}

Hui Ma ,Yinhuan Chen

College of Arts and Law of Wuhan University of Technology, Wuhan Hubei,430070, China

*email: ff6453@sohu.com

\begin{abstract}
In 2007, Chinese the disabled care services began to develop, which has made some achievements, but there are still many problems. The establishment and improvement of the security system for disabled persons not only can better solve the needs of disabled persons, but also can truly protect the rights and interests of disabled persons from being blocked by the obstacles.
\end{abstract}

Keywords:disabled,care,rights and interest,security mechanism

\section{The Present Situation of the Disabled Care System in China}

Some studies show that up to 2016, currently China has a total of 85 million disabled persons, thus affecting 260 million persons' family life.In this large group, the people with psychological disorder and the severe disabled people are the majority of vulnerable groups.More than 14 persons have obtained the foster care, which account for only $0.56 \%$ of the whole disabled persons. In this situation,the problem has increasingly drawn attention to the party and the government in China ${ }^{[1]}$.

Although the construction of service facilities for disabled persons has also been fully developed (as chart 1 shows), it still does not meet the needs of the protection of the rights and interests of disabled persons. There is a lack of legislative and judicial system about a security mechanism for disabled people in China. The legal regulations about the disabled care have not yet been established. In the meantime,the existing laws and regulations have very few provisions on caring for the disabled,which restricts the comprehensive development of the disabled care.To some extent, it may produce the conflicts between the disabled home care and the society in some areas of China.

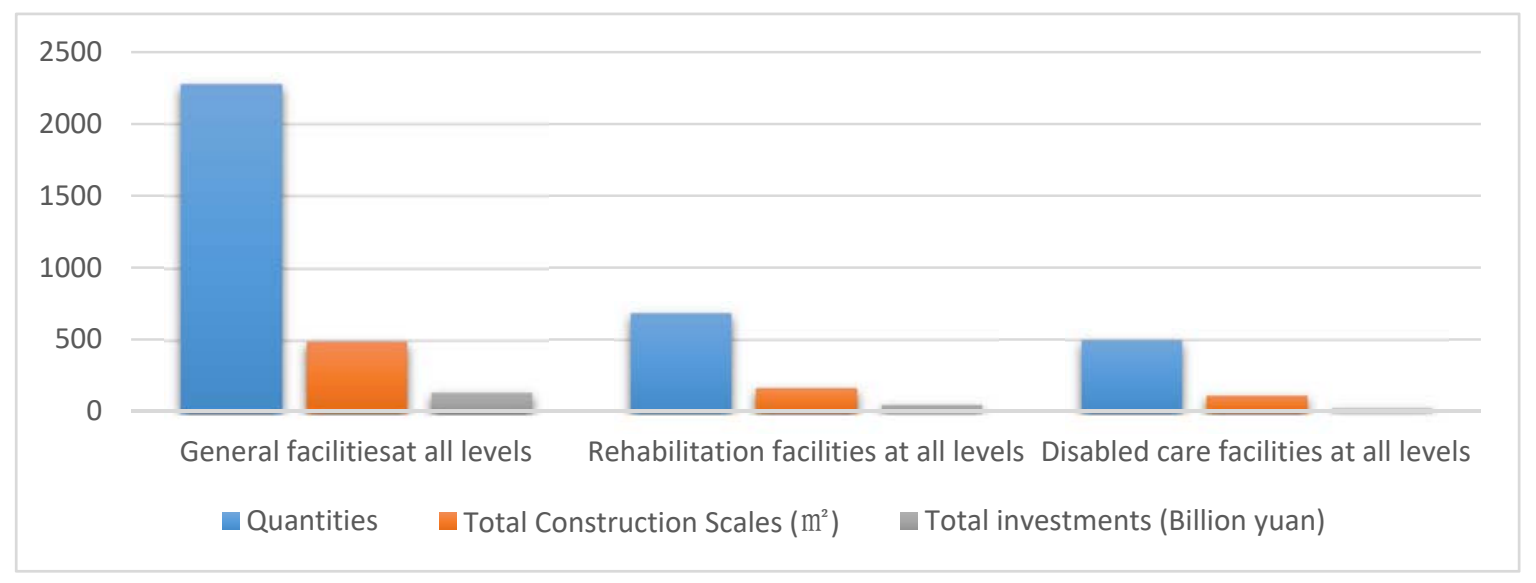

Chart 1: Facilities Built and Put into Use for the Disabled at All Levels in China

\section{The Definition of the Disabled Persons' Rights and Interests and its forms of Expression}

\subsection{The Definition of the Disabled Persons' Rights and Interests}

The people that the disabled care institutions serve are divided into three categories, which are intellectual, spiritual, severe limb. "Care" not only includes the basic care, nursing care and other basic meanings of "support", also includes developing the ability of self-care training, sports training, social development training, career and labor 
skills training,treatment, education and employment. ${ }^{[2]}$ The definition of the disabled persons' rights and interests has different meanings from different senses. In its narrow sense, that is, it must be based on the conditions of the disabled care to ensure they have access to health services, in order to content the needs of the disabled persons.In its broad sense, namely, it not only meets the basic living conditions for the disabled,but also ensures that they are accessible to the security services, and they have access to self-care training, career development training, labor skills training, rehabilitation training, treatment and education training, for the sake of guaranteeing that the disabled have the ability of taking care of themselves slowly and can enjoy the economic and social development achievements.Based on this purpose, the Chinese disabled care institutions have been growing quickly(as the chart 2 below shows).

Chart 2: The Distribution of Chinese disabled Care Security Organizations

\begin{tabular}{|l|l|l|l|}
\hline $\begin{array}{l}\text { Types of Institutions for } \\
\text { Disabled Persons }\end{array}$ & Distribution areas & Quantities & $\begin{array}{l}\text { Percentages completed as } \\
\text { planned }\end{array}$ \\
\hline $\begin{array}{l}\text { The Disabled Persons' } \\
\text { Federations }\end{array}$ & $\begin{array}{l}\text { provinces, cities, } \\
\text { counties, townships, } \\
\text { villages }\end{array}$ & $\begin{array}{l}\text { Over 93.7\% that have been } \\
\text { built }\end{array}$ \\
\hline $\begin{array}{l}\text { The Associations of } \\
\text { Disabled Person }\end{array}$ & $\begin{array}{l}\text { Provinces, cities and } \\
\text { counties }\end{array}$ & 1.6 million & $\begin{array}{l}\text { Over 92.7\% that have been } \\
\text { built }\end{array}$ \\
\hline $\begin{array}{l}\text { The Disabled Persons in } \\
\text { the Federations }\end{array}$ & $\begin{array}{l}\text { provinces cities , } \\
\text { counties, village } \\
\text { disabled persons, } \\
\text { federations }\end{array}$ & $\begin{array}{l}\text { Overe than 53\% of the total } \\
\text { disabled persons }\end{array}$ \\
\hline
\end{tabular}

\subsection{The Forms of Expression of the Disabled Persons' Rights and Interests.}

"The Constitution of the People's Republic of China" shows that the disabled persons have the right to be assisted in the case of incapacity of work, so that they could receive the disabled care from institutions and get some services in the institutions.And it also reflects the State's protection of the right to rehabilitation of persons with disabilities. According to the needs and characteristics of the disabled persons, the disabled care institutions should establish appropriate training programs to guide persons with disabilities to train, so as to ensure their basic livelihood and help them to recover.

Some provisions of "the Education Law of the People's Republic of China" reflect the State's protection of the right to education for persons with disabilities, and the institutions should popularize simply the knowledge of etiquette and gender as well as other basic social behavioral norms and common sense about the disabled care services to persons with disabilities in an appropriate manner.According to the different characteristics of the disabled, the institutions can carry on different cultural and educational activities to help the disabled improve social consciousness and adaptability. According to "People with disabilities act of the Peoples Republic of China", it shows that China fully protects the cultural life rights of persons with disabilities. the disabled care organizations should organize appropriate sports and recreational activities, and organize competitions according to the actual situations,so as to fully demonstrate the abilities of persons with disabilities, and to make them own the basic ability of social interaction.

In March 2010, the General Office of the State Council of China responded to the needs of Chinese Disabled Persons' Federation and other organizations, which has further strengthened the construction of the disabled service systems and improved the disabled care service systems for intellectual disabled persons and other vulnerable groups, and in which conditions it can provide the chances of life care, rehabilitation, re-employment and treatment, thus making the disabled enjoy cultural,sports, psychological counseling, recreation and other services. 


\section{The Protection of Rights and Interests of the Disabled Care in China is Imperfect}

\subsection{The Insufficiency of Legal Security Mechanism}

Chinese laws on protecting the rights and interests of the disabled care are very scarce,and there is only "People with disabilities act of the Peoples Republic of China",of which the provisions are simply general principles,and they lack the specific operational requirements about protecting the rights and interests of the disabled care.However, these problems can only rely on the government's policies.Their randomness and opacity lead to the mixed qualification of the disabled care institutions, and cause the uneven charges, the inferior level of service and the disorder market administration.

\subsection{There is not Enough Funds for the Disabled Care Institutions}

With regard to the financial operation of the disabled care institutions in China, the funds mainly stem from three aspects: state investment, social donation and family burden, Among which state investment occupies the most important position. ${ }^{[3]}$ At present, the national, social and local government financial support are obviously insufficient.For example, in 2015 the Yinchuan municipal government gives local financial support to the local 2892 disabled persons, so that they are able to obtain the disabled care, in which the disabled persons lodged in families can get 2000 Yuan per person per year, the disabled persons receiving day care could get 1,000 yuan per person per year, and the disabled persons enjoying the home care may get 700 yuan per person per year . ${ }^{[4]}$

\subsection{Tthe Number and the Scale of the Disabled Care Institutions are Hard to Meet the Real Needs}

People with disabilities in China who are eager to acquire the care accounts for $40 \%$ of the total population of 85 million people with disabilities, or nearly 30 million people with disabilities eagerly need government or social care and support services, while currently the number of the disabled care institutions is far from adequate to sufficiently provide day care, lodging care and comprehensive care in China. The chart 3 below can tell us that the disabled care institutions, up to 2015 , are far from satisfying the needs of disabled persons. ${ }^{[5]}$

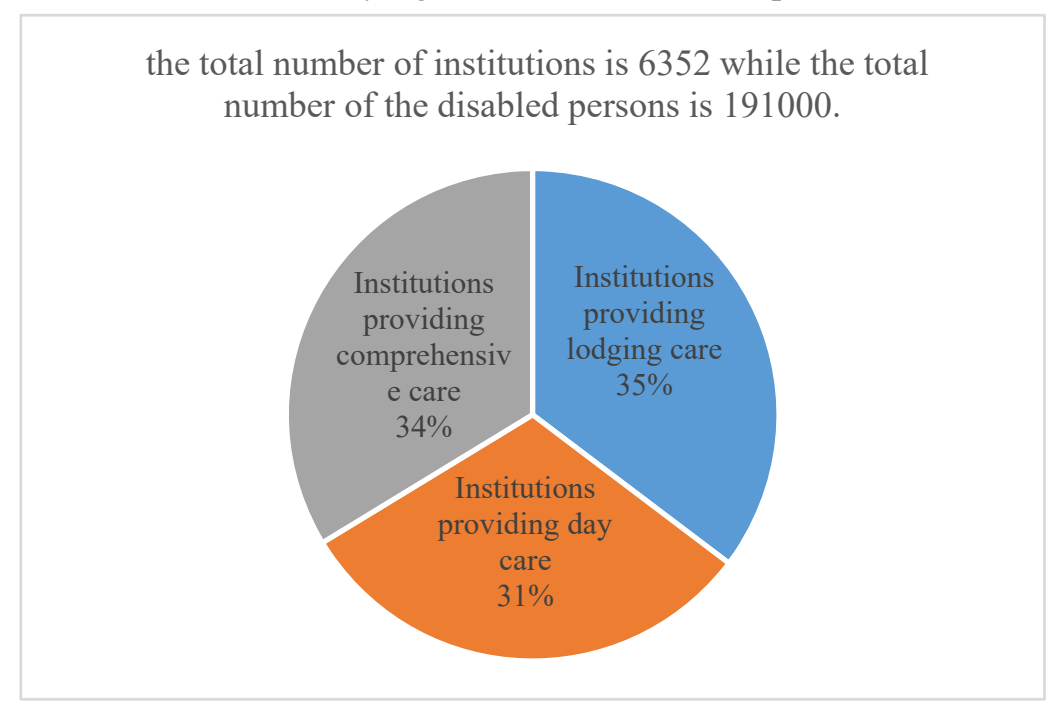

Chart 3: The Comparative Proportion of the Disabled Care Institutions Providing Different Services of China in 2015

\section{The Recommendations for Improving the Security System on the Rights and Interests of the Disabled Care}

\subsection{The Legislative System about the disabled care should be Perfected}

First of all, relevant laws and regulations should be made in China.There are a lot of gaps in the legislation system of the disabled care, so I believe that only are the relevant laws and regulations made and improved, the development of the disabled care can be achieved. At the same time, the disabled care separate laws should have 
the specific objects of care and services.Currently "People with disabilities act of the Peoples Republic of China" doesn't stipulate the ages and types of persons with disabilities in the disable care institutions.So the disabled care separate laws shall specify the community day care ,home care and other ways of care, at the same time, it should sort out the fields of application of the different care. ${ }^{[6]}$

\subsection{Developing the Judicial Relief Channels for the Rights and Interests of the Disabled Care}

First, the disabled "green channels" should be established.In order to facilitate the participation of persons with disabilities in suit, barrier-free facilities and other green channels should be built within the courts or the procuratorates. Second, the burden of proof principle converted should be applied. In the field of personal property damage compensation process among the disabled, in order to facilitate the participation of persons with disabilities in suit, the disabled should be reduced their burden of proof appropriately. The author recommends that the courts could give preferential policies to persons with disabilities, such as the disabled persons with financial difficulties can be deferred, reduced or exempt from litigation costs.

\subsection{Increasing the Ways of Financial Security for the Rights and Interests of the disabled care}

In order to ensure the smooth development of Chinese the disabled care, the state should increase its investment in the disabled, especially the disabled care, and raise the support standards for the disabled care institutions appropriately.It could also increase the directed support for the rights and interests of the disabled care, and this financial support can be drawn from the disabled employment security funds in the appropriate proportion for the disabled care. At the same time, a special fund for the disabled care should be set up as a platform to receive donations from all walks of life, so as to expand the funding sources of the institutions, to ensure the quality of service and to improve the service level. ${ }^{[7]}$

\section{Reference}

[1] Li Yanyang:Legal Norms for the Protection of Persons with Disabilities [M]. Beijing: China Folk Art Publishing House(2006: 1).

[2] This sentence came from the Notice of China Disabled People's Federation on the Issuance of the Main Document about National Mental and Mental the disabled care's Conference Spirit,2007.

[3] Jiang Yiwen and Liu Danlin:Three Problems Restricting the Development of the Service Industry [J]. China Disabled Persons, 2010 (1): 62.

[4] Li Huijuan:2892 People with Disabilities in the City Were Subsidized 2.57 Million Yuan [N]. Yinchuan daily, 2015-3-3 (1).

[5] The data came from "2015 Disabled People's Development Bulletin".

[6] Fan Minglin:Social Work Theory and Practice [M]. Shanghai: Shanghai University Press, 2006: 119.

[7] Xu Hong:Care and Support System for the Disabled: Implications, Challenges and Policy Options [J] .Research on the Rights of Persons with Disabilities, 2014 (1): 53.

[8] This essay was supported by " 2013 Chinese Social Science Fund Projects on the Security Mechanism of the disabled care" and "Humanities and Social Sciences Innovation Research Projects on the Legal Security Mechanism of the disabled care of Wuhan University of Technology(Item no. 2012-Ib-031)". 